\begin{tabular}{c} 
Volume and Issues Obtainable at Center for Sustainability Research and Consultancy \\
Journal of Business and Social Review in Emerging Economies \\
ISSN: 2519-089X (E): 2519-0326 \\
Volume 3: Issue 1 June 2017 \\
CSRᄃ \\
Journal homepage: www.publishing.globalcsrc.org/jbsee \\
\hline
\end{tabular}

\title{
Role of Ethical Leadership in Online Sustainability Reporting
}

\author{
${ }^{1}$ Nazahah Rahim, ${ }^{2}$ David Biggs, ${ }^{3}$ Doaa Aly \\ ${ }^{1}$ Othman Yeop Abdullah Graduate School of Business (OYAGSB), Universiti Utara Malaysia, 06010 Sintok, \\ Kedah, Malaysia.nazahah@uum.edu.my \\ ${ }^{2}$ University of Gloucestershire, University of Gloucestershire, Francis Close Hall, GL504AZ, Cheltenham, \\ Gloucestershire, United Kingdom.dbiggs@glos.ac.uk \\ ${ }^{3}$ University of Gloucestershire, The Park, GL502RH, Cheltenham, Gloucestershire, United Kingdom. \\ daly@glos.ac.uk
}

\begin{tabular}{l}
\hline ARTICLEDETAILS \\
\hline History \\
Revised format: May 2017 \\
AvailableOnline: June 2017 \\
\hline Keywords \\
Sustainability Reporting, \\
Corporate Social \\
Responsibility, CSR, Online, \\
Disclosure, Ethical \\
Leadership \\
\end{tabular}

JEL Classification:

Q56, Q59, M14, M19

\begin{abstract}
Purpose: Corporate scandals are still making headlines in the news. Stakeholders are demanding transparency through more information disclosure in order to curtail this problem and to regain trust. On the other hand, businesses are finding better ways to communicate not only financial but also non-financial information to their stakeholders. With the rise in internet applications, online sustainability reporting could be a solution to this problem. However, information disclosures via the internet particularly on websites are still limited. Prior studies look into antecedents such as firm specific characteristics and corporate governance mechanisms but this study will take a different leap, investigating the role of ethical leadership in online sustainability reporting.

Design/Methodology/Approach: Cross-sectional approach will be applied through content analysis and survey. A disclosure index will be used. The explanatory variables will be extracted from questionnaires which will focus on respondents' opinion of their supervisors.

Findings: Since this paper is conceptual in nature, the expected result will indicate that ethical leadership components could play a role in online sustainability reporting practices.

Implications/Originality/Value: This study will provide a new insight for corporate leaders, academics and policymakers on how ethical leadership could play a role in online sustainability reporting as well as enhance accountability through online disclosures. The empirical evidence will provide support for ethical leadership as potential antecedents of online disclosures, which has been understudied.
\end{abstract}

(C) 2017 The authors, under a Creative Commons Attribution-

NonCommercial 4.0

Corresponding author's email address: nazahah@uum.edu.my

Recommended citation:Rahim,N., Biggs,D. \&Aly,D., (2017). Role of Ethical Leadership in Online Sustainability Reporting.Journal of Business and Social Review in Emerging Economies, 3(1) 121-130.

DOI:https://doi.org/10.26710/jbsee.v3i1.85

\section{Introduction}

One of the major reasons for corporate scandals is the lack of a good information disclosure and transparency system (Elsayed, 2010). Companies need to make necessary improvements in order to develop better disclosure and transparency system. One of the ways is by providing a more efficient information disclosure system with the use of the internet reporting for faster and better communication. 
The transparency provided by the internet reporting ensures that any irresponsible corporation actions will be exposed and punished (Coombs \& Holladay, 2013). More importantly, the impact of the internet cannot be understated as corporate misbehaviors are disseminated in real time, 24 hours a day, to a global audience (Miles, 2012).

Most companies tend to focus on financial reporting than non-financial reporting. Financial reporting is mainly retrospective and based on a company's past performance, whereas non-financial reports can provide investors and other stakeholders with indications about the future potential of a company, which helps stakeholders to better understand a company's overall performance, business strategy, and growth prospects (Perrini, 2006). Therefore, the focus of this study will be on Corporate Social Responsibility (CSR) or sustainability reporting which is the most widely communicated non-financial information. It covers various areas of an organization and gives sustainability-related information, including information on economic, environmental, social and governance performance (GRI, 2015). Since the internet is now the prime vehicle through which organizations can build relationships with stakeholders, the relationships are strengthened and developed through the flow of information and rich dialogue, creating transparency.

The advantage of internet reporting overcomes the limitations of paper-based communication, thus influencing the style and amount of reporting (Isenmann et al., 2007). Compared to traditional printed reports, the internet offers more opportunities to communicate corporate information and allows a wealth of up-to-date, unofficial, critical and alternative channels of information to compete with official channels (Homayoun\& Abdul Rahman, 2010). This may result in companies embodying socially responsible attributes on their websites, such as statements on their use of organic or chemical-free ingredients, which leads to awareness among consumers that the goods they are purchasing have been produced in a socially responsible manner. Not only that, the transparency equally creates the impression that internet sustainability reporting or online sustainability reporting is accurate, because it is assumed that the internet has the capacity to expose any irresponsible corporate conduct (Coombs \& Holladay, 2013).

There is no doubt that internet reporting offers various benefits to companies and their stakeholders in terms of increased transparency, reputation, trust, information accuracy, faster information dissemination and many more aspects. Taking all of these aspects into account, it is vital that organizations utilize online capabilities to succeed. However, one highly studied factor in organizational success, leadership is often overlooked (Bass, 2000). Leaders are the backbones of companies and without them any corporate action would be at a halt. Leadership has been identified as crucial to the success or failure of organizations. Yet, in today's corporate world, great concern is still directed towards the actions of some leaders, which have resulted in the collapse of many corporations. Whether centered on corruption, bribery or fraud, these cases tend to be traced back to the leaders' responsibility (or irresponsibility) when put in charge of managing a company. The link with sustainability is that any weakness in leadership, in the form of mismanagement or even corruption, can lead to difficulties in implementing sustainability efforts effectively (Abugre, 2014).

However, studies have ignored the role of leadership in sustainability reporting studies. Studies have argued that much of the literature on sustainability reporting to date focuses on justifying CSR, and the various activities associated with CSR, in economic terms (Margolis \& Walsh, 2003; Basu\& Palazzo, 2008). As a result, the emphasis on human-related antecedents in justifying sustainability actions has been left unexplored - for example, in terms of leadership components that triggers or shape corporate actions (Waldman et al., 2006; Basu\& Palazzo, 2008). Despite a growing body of study documenting sustainability related scenarios, knowledge of organizational antecedents to sustainability remains in its infancy (Angus-Leppan et al., 2010). Moreover, leading scholars have also pointed out that the lack of study on external and internal institutional factors might shape sustainability activities in the first place and have thus called for more study on its organizational antecedents (Margolis \& Walsh, 2003; Du et al., 2013). Hence, this study provides much-needed empirical evidence concerning the roles of ethical leadership in online sustainability reporting initiatives. 
This study will address the above gap through examining the relationship between ethical leadership and the extent of online sustainability reporting. This study will employ the stakeholder theory to explore the role of ethical leadership components in determining the extent to which firms engage in online sustainability reporting. This study therefore endeavors to answer this research question - is there any significant association between ethical leadership and online sustainability reporting?

This conceptual paper is organized into several sections. The next section provides the literature review, followed by the development of the hypothesis. The subsequent section presents the proposed research method and finally, the concluding remarks.

\section{Literature Review}

Previous studies have focused on the communication of non-financial information via the internet as well as measuring its extent of disclosure (Homayoun\& Abdul Rahman, 2010; Lakatos et al., 2012; Amran, 2012; Che Hassan et al., 2012). Alongside these studies, researchers have also examined the determinants and motivations for practicing online sustainability reporting (Nejati\&Amran, 2009). These determinants include firm specific characteristics and corporate governance mechanisms such as company size, profitability, return on investment (ROI), board structure, board size, CEO duality and many more. Although studies evaluating the extent of sustainability reporting and examining company's motivations to do so are abundant, most of these factors are economic in nature, mainly financial and accountingrelated variables. It is found that the majority of studies looking into sustainability and leadership collectively focused on leadership styles, examining various leadership styles such as the transformational leadership style, transactional leadership style, autocratic leadership style and charismatic leadership style (Angus-Leppan et al., 2010; Strand, 2011; Du et al., 2013; Metcalf \& Benn, 2013). It is also found that most prior studies are undertaken on general sustainability issues or general sustainability practices, examining the interplay of leadership styles with general sustainability practices such as engagement in strategic CSR (Waldman et al., 2006) and engagement in institutional CSR practices (Du et al., 2013). Nonetheless, none has examined the interplay with a more specific sustainability practice such as online sustainability reporting. Hence, there is a gap here, and there is a need to study this issue in depth.

Given the financial devastation that resulted from the demise of corporations such as Enron and WorldCom, which occurred largely because of the failure of their leadership, it is crucial to look at ethical components of leadership. This is because ethical leadership stands alongside and complements leadership practices by outlining ways in which leaders can lead ethically and ensure the ethics of business practices in their organizations, and hence this component cannot be ignored (Resick et al., 2006). The increased focus on ethical leadership should help organizations avoid the economic pitfalls that have affected not only members of individual organization but also the communities which these organizations serve (Resick et al., 2006). For that reason, this study tries to fill this gap by investigating the association between ethical leadership components and the disclosure of sustainability related information on the internet.

This study will employ the stakeholder theory to understand the topic in question. In the 1980s, the prominent concept of stakeholder theory was discovered. It was inspired by Edward Freeman's landmark book "Strategic Management: A Stakeholder Approach" that has triggered the thinking around stakeholders. Freeman's notion of a stakeholder is "any group or individual who can affect or is affected by the achievement of the organization's objectives" (1984, p. 31). Freeman's stakeholder theory asserts that managers must satisfy a variety of constituents such as the employees, customers, suppliers, local community, organizations who can influence firm outcomes. According to this view, it is not sufficient for managers to focus exclusively on the needs of shareholders, or the owners the corporation. In relation to this, the stakeholder theory implies that it can be beneficial for the firm to engage in certain CSR activities that non-financial stakeholders perceive to be important (Miles, 2012). 
In the traditional view of the firm, the shareholders are the owners of the company, and the firm has a duty to put their needs first, to increase value for them and nothing else (Friedman, 1970). However, the stakeholder theory argues that there are other parties involved, including other stakeholders such as the local communities, consumers, suppliers, governmental bodies, trade unions and political groups who have the capacity to affect and be affected by the firm as well. This has challenged Friedman's traditional perception of CSR and proposed that CSR and the concept of stakeholders complement and reinforce each other (Griseri\&Seppala, 2010).

Nevertheless, according to Miles (2012), the concept of 'stakeholder' per se cannot be considered as accrediting a vital element to corporations, but the process of stakeholder management or adopting a stakeholder theory approach to running a corporation is significant, as there are many benefits associated with it (Miles, 2012). This view is however contrary to the agency theory which concentrates only on the relationship between management and the shareholders. With regards to the purposes of disclosure, the stakeholder theory implies that other stakeholders such as employees, consumers and communities have the same right to the corporate information, similar to the shareholders.

Freeman (2010) has attempted to relate leadership with stakeholder theory. He has justified that if the management style and the skills of the managers and firm are not conducive to negotiating with stakeholders, there is an equal chance for 'misfit'. The leadership task using a stakeholders approach is to understand and take into account the fact that stakeholders provide the setting or the context for managerial decisions (Basu\&Pallazo, 2008). The decisions must integrate a number of managerial tasks which include people, because the basic element of any framework for organizations and the central building block of the firm are its people (Basu\&Pallazo, 2008). In the context of what needs to be further examined, the 'people' element can be described as the firm leaders who are the drivers of all the organizational tasks, which in turn affect 'people' who are the stakeholders comprising of the employees, investors, consumers, community and many more.

Nevertheless, there is a big threat for companies these days to satisfy the high expectations and the various needs of stakeholders. Information disclosure can be used by firm leaders to manage the perceptions of different stakeholders either to obtain their support or avoid their opposition. As such there is a variety of motivations for companies to disclose voluntary information such as sustainability related information. One of these motivations is to manage particular stakeholder groups. To achieve this goal, new technology, namely, the internet can help companies to satisfy these needs which can be done through a better disclosure method via the internet (Bolivar \& Garcia, 2004). Since these stakeholders need a greater level of transparency, the internet as a new disseminating information tool can also support ethical and sustainable conducts (Elsayed, 2010).

\subsection{Ethical Leadership}

Brown et al. (2005) defined ethical leadership as "the demonstration of normatively appropriate conduct through personal actions and interpersonal relationship, and the promotion of such conduct to followers through two-way communication, reinforcement and decision-making" (p.120). Caldwell et al. (2008) defined ethical leadership as the honoring owed to employees, stakeholders and society in the pursuit of long-term wealth creation. For leaders to be perceived as ethical leaders and to be able to influence desired outcomes, they must be perceived as attractive, credible, open and honest, and treat employees fairly and considerately (Brown et al., 2005). Resick et al. (2006) identified six key attributes that depict characteristics of ethical leadership, including character and integrity, ethical awareness, community/people orientation, motivating, encouraging and empowering, and managing ethical accountability. Kalshoven et al. (2011) improvised and extended the list and suggested seven dimensions of ethical leadership components, comprising people orientation, fairness, power sharing, concern about sustainability, ethical guidance, role clarification, and integrity. This concept of ethical leadership dimension by Kalshoven et al (2011) will be applied in this study as it covers variations of ethical 
leadership components, and appropriate in justifying any association with non-financial information disclosed on websites.

According to the stakeholder theory, companies are in a web of relationships with stakeholders and as a result, this web of relationships constitute the elements of mutuality, giving-and-taking, and power sharing that are explicit in terms of stakeholder engagement and stakeholder relationship (Waddock, 2005). The stakeholder theory suggests that companies and their managers should recognize that they are in the same relationship with each other, and that their actions, mutually affect each other as observed by Freeman (1984). Similarly, in engaging with the stakeholders, ethical leaders have the obligation to share financial and non-financial information with stakeholders; hence, the use of the online reporting is necessary to ensure information is disseminated effectively and efficiently.

The component of people orientation in ethical leadership reflects that a leader cares about, respects and supports subordinates and, where possible, ensures that their needs are met (Conger \&Kanungo, 1994; Trevino et al., 2000). Individual values and people-oriented organizations are the most powerful predictors of Purchasing Social Responsibility (PSR) (Salam, 2007). This implies that people orientation could play a role in any sustainability efforts, including in purchasing and procurement activities. Ethical leaders make principled and fair choices and trustworthy and honest decisions, do not practice favoritism and take responsibility for their own actions (Trevino et al., 2000; Brown et al., 2005; De Hoogh\& Den Hartog, 2008). In the case of online sustainability reporting, a "fair" manager would feel obliged to disclose as much information as possible to all stakeholders. This is to ensure that not only the shareholders or owners, but also other stakeholders such as customers, suppliers and employees are updated with the same level of corporate information.

Similarly, in engaging with stakeholders, managers or leaders have an obligation to share financial and non-financial information with stakeholders, hence online reporting must be used to ensure information is disseminated effectively and efficiently. The notion of power sharing reflects sharing of responsibilities and in this case, power sharing is manifested through sharing of corporate information. Waldman et al. (2006) claimed that, in sustainability, it is important that leaders have broader views of others in the firm, such as employees, society and the natural environment. "Concern about sustainability" entails leaders paying attention to sustainability issues, such as recycling, community services and employee rights. One way of being sustainable involves utilizing the internet capabilities in business processes. With today's technology, the internet is used extensively by individuals as well as businesses. Ethical leaders who are concerned about sustainability would want to use a more sustainable way to disseminate information, at the same time ensuring that as much information as possible is communicated to the widest audience, but at minimal cost hence the use of online sustainability reporting.

It is argued that ethical awareness should be kept in shape as it is key to organizational success. This is in line with Trevino et al. (2000), where leaders convey standards regarding ethical conduct. They set rules and codes of conduct which become guidelines to members of the organizations. A study by Del Baldo (2012) found that, in family SMEs, the presence of the ethical values of the entrepreneurial family represents a fundamental driving force towards the adoption of practices and communication tools of sustainability. According to him, ethical values are linked to the personal attributes of those entrepreneurs who lead their businesses towards better adoption and communication of sustainability. Ethical leaders promote transparency as, according to Brown et al. (2005), such leaders are transparent and engage in open communication. This is to ensure that subordinates understand what is expected of them and know when their performance is up to standard. In addition, they will know exactly how they can contribute to meeting the organization's goals. Leaders feel more confident when given clear responsibilities and requirements because this gives them room and freedom to operate (Ole Pors\& Gustav, 2002). As a result of this, they can carry out their tasks better and perform better. 
The notion of integrity is important with regard to online sustainability reporting. This is because, in sustainability reporting, integrity plays a large role in the way stakeholders and investors perceive corporate value. Companies increasingly want to demonstrate the quality and reliability of the sustainability related information contained in their sustainability reports. This enhances companies' credibility and integrity, thus influencing stakeholder perceptions of their ethical and moral outlook (KPMG, 2011). Verissimo and Lacerda (2015) found that leaders rated with higher integrity are engaged in sustainability practices. Therefore, it could be hypothesized that the extent of online sustainability reporting is significantly associated with ethical leadership (people orientation, fairness, power sharing, concern about sustainability, ethical guidance, role clarification and integrity). Figure 1 depicts the conceptualized framework of the variables involved.

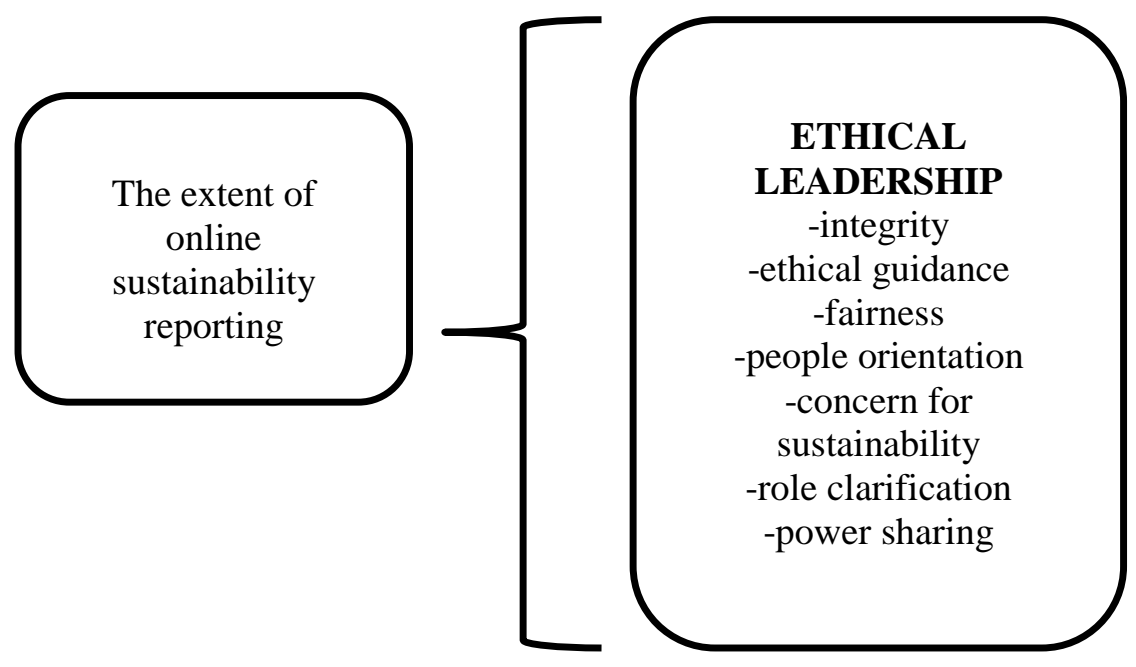

Figure 1: The overview of the conceptualized relationships

\section{Method}

This study will employ non-probability sampling design with snowball sampling. The non-probability sampling is chosen due to the unknown exact population of the employees due to the Personal Data Protection Act 2010 restriction and vague characteristics of the population of employees as company's information such as financial information and employees' information are confidential. A snowballing technique will involve a process in which a few appropriate individuals are located and asked for the names and addresses who might also fit the sampling requirements (Oppenheim, 2003). This approach will be repeated a number of times to yield substantial number of respondents. However, it will be difficult to know how accurately these respondents would represent the population, as it will not be able to generalize the finding to the wider population of the employees (Oppenheim, 2003). Even though the usage of non-probability sampling technique will limit the ability of this study to be generalized in other contextual settings, this study will provide meaningful forms of evidence on the role of ethical leadership towards online sustainability reporting. Another concern pertaining to sampling is the sample size. In this study, sample size is a critical factor as univariate and multivariate analyses will be applied to test the hypothesis. Hair et al. (2010) stated that a sample size of 200 or more is good enough to be analyzed using such statistical techniques. This study will involve at least 200 respondents, a number that will be useable for further analysis.

First, 100 websites of top public listed companies in Malaysia will be checked against a CSR checklist called sustainability index. The index will include 60 items of online sustainability reporting grouped according to four dimensions of CSR, which are community, workplace, marketplace and environment.Dichotomous approach will be used to code whether or not an item would be disclosed, so as to avoid subjectivity in assessing whether partial disclosure occurred. In scoring the disclosure items, a score of ' 1 ' is awarded if an item is disclosed and ' 0 ' otherwise. 
Second, the explanatory variables will be extracted from a questionnaire survey. The items in the questionnaire will be based on the Ethical Leadership at Work (ELW) scale developed by Kalshoven et al. (2011). The questionnaire will focus on respondents' opinion on ethical leadership of their supervisors at their respective companies. The response scale ranges from 1, "strongly disagree", to 5, "strongly agree". Since the use of online sustainability reporting is more prominent among public listed companies, purposive sampling will be used where the respondents will be purposely selected among employees of Malaysian public listed companies. Snowballing technique will also be applied to disseminate the questionnaires where it involves a process in which a few appropriate individuals are located and asked for their contacts that might fit the sampling requirements. This approach will be repeated a number of times to yield the substantial number of respondents. Quantitative data will be examined using SPSS statistical tool, specifically multiple regression.

\subsection{Pilot study}

A pilot study was conducted for reliability and validity purposes. First, to ensure the reliability of the disclosure checklist, a second coder examined and scored 40 websites from the sample companies. The results from the second coder were compared and analyzed with the present researcher's score. The results suggested that the researcher's score was in substantial agreement with the second coder indicating minimal subjectivity in scoring the disclosures on the websites of the sample companies. The correlation analysis also showed that the two scores were highly correlated which indicates that there was no significant bias between the scorers (Pearson product-moment correlation coefficient, $\mathrm{r}=0.97, \mathrm{p}$-value $=$ .000). Second, to ensure the reliability of the survey, the questionnaire was piloted with 40 respondents. As show in Table 1, the reliability test results for both instruments are acceptable and can be used for this study.

Table 1: The results of reliability tests for the pilot study

\begin{tabular}{lcc}
\hline & N of items & Cronbach alpha \\
\hline $1^{\text {st }}$ category: Community & 16 & 0.874 \\
$2^{\text {nd }}$ category: Workplace & 18 & 0.824 \\
$3^{\text {rd }}$ category: Marketplace & 11 & 0.689 \\
$4^{\text {th }}$ category: Environment & 15 & 0.893 \\
People orientation & 7 & 0.866 \\
Fairness & 6 & 0.714 \\
Power sharing & 6 & 0.814 \\
Concern for sustainability & 3 & 0.791 \\
Ethical guidance & 7 & 0.951 \\
Role clarification & 5 & 0.954 \\
Integrity & 4 & 0.946 \\
\hline Total & $\mathbf{9 8}$ & \\
\hline
\end{tabular}

\section{Conclusion}

This paper will address the issue of whether ethical leadership plays any role in online sustainability reporting. The expected result will indicate that ethical leadership plays a role in online sustainability reporting practices. Two dimensions, online sustainability reporting and ethical leadership will be the foundations of this study guided by the stakeholder theory. An implication of this is the possibility that this multidisciplinary study to be replicated and be benefited by others. A key practical implication of this study will be the identification of ethical components of leaders that could enhance online sustainability reporting. This is critical as companies nowadays are bombarded by increasing demands from stakeholders for better transparency and more information disclosure. The leaders are then responsible to fulfill this demand through better reporting mechanism which include adopting online sustainability 
reporting. Problems such as the $1 \mathrm{MDB}$ issue could be avoided if companies practice the right corporate disclosure mechanism. This study will identify a number of specific ethical leadership components that are associated with online sustainability reporting. Organizations can train their managers in this regard, which can also become a part of employee selection packages when identifying new managerial talent. Similarly, organizations can improve their training and leadership development processes by focusing on these dimensions.

\section{References}

Abugre, J. B. (2014). Managerial role in organizational CSR: empirical lessons from Ghana. Corporate Governance, 14(1), 104-119.

Amran, A. (2012). Exploring Online Sustainability Disclosure among Malaysian Company.Procedia Social and Behavioral Sciences, 65(0), 761-767.

Angus-Leppan, T., Metcalf, L., \& Benn, S. (2010). Leadership styles and CSR practice: An examination of sensemaking, institutional drivers and CSR leadership. Journal of Business Ethics, 93(2), 189213.

Basu, K., \& Palazzo, G. (2008). Corporate Social Responsibility: A Process of Sense making. Academy of Management.The Academy of Management Review, 33(1), 122-136.

Bass, B. M. (2000). The future of leadership in learning organizations.Journal of Leadership \& Organizational Studies, 7(3), 18-40.

Bolivar, M. P. R., \& Garcia, B. S. (2004). The corporate environmental disclosures on the internet: the case of IBEX 35 Spanish companies. International Journal of Accounting, Auditing and Performance Evaluation, 1(2), 215-266.

Brown, M. E., Trevino, L. K. \& Harrison, D. A. (2005). Ethical leadership: A social learning perspective for construct development and testing. Organizational Behavior and Human Decision Processes, 97(2), 117-134.

Caldwell, C., Hayes, L. A., Bernal, P., \& Karri, R. (2008).Ethical stewardship-implications for leadership and trust.Journal of Business Ethics, 78(1-2), 153-164.

Che Hassan, N. H., Yusoff, H., \&Yatim, N. (2012).Disclosing social responsibility information via the internet: A study on companies in Malaysia.International Journal of Arts and Commerce, 1(5), 83-96.

Conger, J. A., \&Kanungo, R. N. (1994). Charismatic leadership in organizations: Perceived behavioral attributes and their measurement. Journal of Organizational Behavior, 15(5), 439-452.

Coombs, W. T., \& Holladay, S. J. (2013). The pseudo-panopticon: The illusion created by CSR-related transparency and the internet. Corporate Communications, 18(2), 212-227.

Del Baldo, M. (2012).To the roots of CSR and sustainability: The "proximity" to the territory: The italian family SMEs' experience. Paper presented at the 96-102. Retrieved from http://search.proquest.com/docview/1285445165 accountid=27114

De Hoogh, A. H., \& Den Hartog, D. N. (2008). Ethical and despotic leadership, relationships with leader's social responsibility, top management team effectiveness and subordinates' optimism: A multimethod study. The Leadership Quarterly, 19(3), 297-311.

Du, S., Swaen, V., Lindgreen, A., \& Sen, S. (2013). The roles of leadership styles in corporate social responsibility.Journal of Business Ethics, 114(1), 155-169.

Elsayed, A.N.M.E. (2010). The key determinants of the voluntary adoption of corporate internet reporting and its consequence on firm value: Evidence from Egypt. University of Plymouth (United Kingdom).

Freeman, R. E. (1984). Strategic Management: A Stakeholder Approach. Boston: Pitman.

Freeman, R. E. (2010). Strategic Management: A Stakeholder Approach. Cambridge University Press (reissue)

Friedman, M. (1970).The Social Responsibility of Business Is to Increase Its Profits. New York Times Magazine, 13 September, 22-26.

Global Reporting Initiative (GRI).(2015). About Sustainability Reporting. Retrieved from https://www.globalreporting.org/reporting/ 
Griseri, P. and Seppala, N. (2010).Business Ethics and Corporate Social Responsibility. Hampshire: Cengage Learning.

Hair, J. F., Black, B., Babin, B., \& Anderson, R. E. (2010).Multivariate Data Analysis (7th ed.). Pearson Prentice Hall. Up. Saddle River NJ.

Homayoun, S., \& Rahman, R.A. (2010).Determinants of web-based corporate reporting among top public listed companies in Malaysia.International Journal of Arts and Sciences, 3(13), 187-212.

Isenmann, R., Bey, C., \& Welter, M. (2007).Online reporting for sustainability issues.Business Strategy and the Environment, 16(7), 487-501.

Kalshoven, K., Den Hartog, D. N., \& De Hoogh, A. H. (2011). Ethical leadership at work questionnaire (ELW): Development and validation of a multidimensional measure. The Leadership Quarterly, 22(1), 51-69.

KPMG.(2011). KPMG International Corporate Responsibility Reporting Survey 2011.

Lakatos, E. S., Gazdac, R. M., \& Dan, V. (2012). Using the Web by Finnish SME's for Corporate Social Responsibility Activities. In Advanced Materials Study, 463, 1186-1189.

Margolis, J. D., \& Walsh, J. P. (2003). Misery loves companies: Rethinking social initiatives by business. Administrative Science Quarterly, 48(2), 268-305.

Metcalf, L. and S. Benn (2013). Leadership for Sustainability: An Evolution of Leadership Ability. Journal of Business Ethics, 112(3), 369-384.

Miles, S. (2012). Stakeholder: essentially contested or just confused?.Journal of Business Ethics, 108, 285-298.

Nejati, M., \&Amran, A. (2009). Corporate social responsibility and SMEs: Exploratory study on motivations from a Malaysian perspective. Business Strategy Series, 10(5), 259-265.

Ole Pors, N., \& Gustav Johannsen, C. (2002). Job satisfaction and motivational strategies among library directors.New Library World, 103(6), 199-209.

Oppenheim, A. N. (2003). Questionnaire design, interviewing and attitude measurement. London: Continuum.

Perrini, F. (2006). The practitioner's perspective on non-financial reporting.California Management Review, 48(2), 73.

Resick, C. J., Hanges, P. J., Dickson, M. W., \&Mitchelson, J. K. (2006). A cross-cultural examination of the endorsement of ethical leadership.Journal of Business Ethics, 63(4), 345-359.

Salam, M. A. (2007). Social responsibility in purchasing: the case of Thailand. International Journal of Procurement Management, 1(1-2), 97-116.

Strand, R. (2011). Exploring the Role of Leadership in Corporate Social Responsibility: A Review.Journal of Leadership, Accountability \& Ethics, 8(4).

Trevino, L. K., Hartman, L. P., \& Brown, M. (2000). Moral person and moral manager: How executives develop a reputation for ethical leadership. California Management Review, 42(4), 128.

Verissimo, J. M. C., \&Lacerda, T. M. C. (2015). Does integrity matter for CSR practice in organizations? the mediating role of transformational leadership. Business Ethics, 24(1), 34-51.

Waddock, S. (2005).10 Corporate responsibility, accountability and stakeholder relationships: will voluntary action suffice?.Handbook on responsible leadership and governance in global business, 180.

Waldman, D.A., Siegel, D.S., \&Javidan, M. (2006).Components of CEO transformational leadership and corporate social responsibility.Journal of Management Studies, 43(8), 1703. 
